Szarkowska, A., Żbikowska, J., \& Krejtz, I. (2014). Strategies for rendering multilingualism in subtitling for the deaf and hard of hearing Linguistica Antverpiensia, New Series. Themes in Translation Studies, 13, 273-291.

\title{
Strategies for rendering multilingualism in subtitling for the deaf and hard of hearing
}

\section{Agnieszka Szarkowska}

University of Warsaw, Poland

a.szarkowska@uw.edu.pl

\section{Jagoda Żbikowska}

University of Warsaw, Poland jagodazbikowska@gmail.com

\section{Izabela Krejtz}

University of Social Sciences and Humanities, Warsaw, Poland iza.krejtz@gmail.com

In this paper we present a set of strategies for rendering the presence of multiple languages in multilingual films in subtitling for the deaf and hard of hearing (SDH): vehicular matching, explicit attribution, colourcoding and linguistic homogenisation. We also report on an online study among deaf and hard of hearing Polish participants regarding their preferences for specific SDH strategies. The findings show that, even when they do not know the foreign language involved, most participants prefer more informative strategies where indications of multilingualism are made explicit.

\section{Introduction}

In recent years an increasing number of film directors have included foreign language dialogue in their scripts by skilfully interweaving various linguistic codes and elevating the status of multilingualism to an important part of the film narrative. O'Sullivan (2011) acknowledges "the shift towards a greater incidence of multilingualism in films" and attributes it to "a growing interest by filmmakers in themes of migration, mobility and intercultural communication" (p. 122). Using more than one language in the film linguistic landscape may be considered "an attempt at instilling veracity in the stories" (Díaz Cintas, 2011, p. 218). It can also be motivated by factors such as the need to preserve authenticity and representational adequacy, globalisation, and specific requirements of the fabula, to name just a few. An important role is also played by the demands of the audience, who expect "characters to behave in a 
'plausible' way"; this in turn means, among other things, "speaking the language suggested by the diegesis" (O'Sullivan 2011, pp. 113-114).

The presence of a foreign language in a film can be marked in different ways. On the one hand, there are numerous instances of mismatch between the languages spoken by the characters in the films and the languages demanded by the representational adequacy of the fabula. A host of Hollywood productions in English but set in other countries and featuring non-English characters can be given as an example. Díaz Cintas (2011) aptly observes that "Hollywood's audacity in linguistically appropriating and anglicising the world's historical and literary heritage is well-known" (p. 217). In many Hollywood productions set in other countries, linguistic verisimilitude is deemed irrelevant. Such disregard for preserving representational adequacy and authenticity can be termed, after Sternberg ${ }^{1}$ (1981, p. 223), 'homogenising'. In Sternberg's (1981) view, linguistic homogenisation "retains the freedom of reference while dismissing the resultant variations in the language presumably spoken by the characters as an irrelevant, if not distracting, representational factor" (p. 224). After all, "Alice does not find it strange to hear the White Rabbit muttering to itself in English, and there is indeed no reason why she should" (Sternberg, 1981, p. 224). On the negative side, however, linguistic homogenisation has been accused of being a way "to hide the diversity of human life behind the mask of a universal language" (Wahl, 2005, p. 2).

Some filmmakers, however, have openly embraced linguistic verisimilitude, creating multilingual diegetic settings and making their characters speak the actual languages required by the fabula, which often serve as "markers of authentic nationhood" (Betz, 2009, p. 89). This approach of "motivated deployment of multiple languages in fiction" (O'Sullivan, 2011, p. 20) can be termed, after Sternberg (1981), 'vehicular matching'. It is often found in what Wahl (2005) termed "polyglot films", that is, films where "languages are used in the way they would be used in reality. They define geographical or political borders, 'visualise' the different social, personal or cultural levels of the characters and enrich their aura in conjunction with the voice" (Wahl, 2005, p. 2).

In what follows we outline a set of strategies for dealing with multilingualism in subtitling for the deaf and hard of hearing (SDH). Departing from a classification of different types of audience and a relevant typology of subtitling, we propose a possible toolkit for rendering the presence of multiple languages on screen in SDH for viewers with hearing impairments. 


\section{Hearing-impaired viewers as a target audience of multilingual films}

Viewers with hearing impairments are not a homogenous group. This umbrella term is used to denote several different groups: the d/Deaf, who tend to have a sign language as their mother tongue and who often consider themselves a linguistic and cultural minority; the hard of hearing, some of whom are pre-lingually hard of hearing while others lost some hearing at a later stage in their lives; and the deafened, who lost hearing after having acquired an oral language. There are also significant differences in the onset (prelingual, perilingual, and postlingual) and degree of hearing loss, ranging from mild, moderate or severe to profound. Hearing-impaired viewers also differ in their proficiency in the national oral language as well as in foreign languages. In this article we examine the question whether preferences for a particular SDH strategy are related to the viewers' proficiency in foreign languages.

Film creators usually conceive of their film with a primary audience in mind, that is, viewers from the home country where the film is made (O'Sullivan, 2011). In the case of Hollywood productions, for instance, the primary audience is usually hearing English-speaking Americans. When a film is exported overseas, to Poland for example, it will be watched by a secondary audience, that is, Poles, and the dialogues need to be translated accordingly.

Not all countries provide their hearing-impaired viewers with an SDH version of foreign films. Thus, in Poland, foreign films are usually shown in the cinemas and released on DVD/Blu-Ray with only one set of subtitles: for hearing viewers. It is implicitly assumed that deaf and hard of hearing people will use the same version of the subtitles as hearing audiences. Or, even worse, no one thinks about deaf viewers and their needs. However, as recipients of multilingual films, deaf and hard of hearing viewers require more information to be provided in subtitles than hearing viewers. Thus, in a sense, hearing-impaired viewers in a foreign market - as in the case of Polish hearing-impaired viewers watching Hollywood productions - can be thought of as a tertiary audience. Not only do they need the dialogue to be subtitled, but they also need an indication of which language is spoken.

\section{Pre-subtitling versus post-subtitling in multilingual films}

Foreign language in a film can be allocated different levels of importance by film creators. The number of foreign language utterances in the dialogue can range from a single sentence, constituting what Díaz Cintas (2011) terms "brushstrokes of exoticism" (p. 217), to a significant portion of the entire dialogue list, having an important role in the diegesis. Filmmakers can decide to explain the meaning of foreign utterances to 
their primary audience, either by including subtitles with the translation or by introducing a figure of a diegetic interpreter. They may also decide that the meaning of the foreign utterances is meant to remain indeterminate to their primary audience, in which case they do not provide any type of translation or explanation in the original version of the film.

O'Sullivan (2011) introduces a useful distinction between two types of subtitling: pre-subtitling and post-subtitling. Pre-subtitling is envisaged by filmmakers at the time of film production, most of the time to translate utterances in a language that is thought to be incomprehensible to the primary target audience. Pre-subtitles are added to part of the dialogue (and are therefore sometimes also referred to as "part-subtitles", see O'Sullivan, 2008) and their target is the primary audience. Films with pre-subtitles, as O'Sullivan (2011) rightly points out, "have no 'original' unsubtitled version" (p. 81). In contrast, postsubtitling is introduced when exporting a film to another language market and consists of a translation of all the dialogue for a secondary target audience, usually in a different language market or country.

Subtitling for the deaf and hard of hearing is an interesting case: it is a classic example of post-subtitling, yet it does not necessarily have to be produced with a foreign audience in mind. For instance, Hollywood productions are usually post-subtitled for the hearing-impaired in English-speaking countries when they are released on DVD/Blu-Ray. When exported to other countries, such as Poland, English dialogue is usually post-subtitled for Polish hearing viewers; ${ }^{2}$ hard of hearing and deaf viewers, however, are usually not provided with subtitles especially designed for them. In other words, as Díaz Cintas (2003) rightly notes, hearing-impaired viewers "are forced to use the same interlingual subtitles as hearing people, when these subtitles are, to all intents and purposes, inappropriate for their needs" (p. 200). This is particularly visible when several languages are spoken in a film, which is increasingly the case in contemporary cinema.

\section{Multilingualism in subtitling for the deaf and hard of hearing}

In what follows we look into how the presence of multiple languages and accents can be made visible to deaf and hard of hearing viewers through subtitling. We discuss five possible SDH strategies and report on the results of a reception study among a group of Polish deaf and hard of hearing viewers. 


\subsection{SDH strategies}

An English-speaking film might contain the French word Bonjour. How can this be signalled in Polish SDH? In Szarkowska et al. (2013) we presented the following five strategies to render such instances of multilingualism in SDH:

(1) VeHICULAR MATCHING, that is, including the transcribed version of the foreign language spoken in the film, as in:

Bonjour.

(2) TRANSLATION + EXPLICIT ATTRIBUTION, which involves translating the foreign-language dialogue and indicating in brackets that another language is spoken, as in:

[IN FRENCH] Good morning.

(3) TRANSLATION + COLOUR-CODING, that is, translating the foreignlanguage dialogue and colour-coding it, without explicitly naming the language each time it is used, as in:

Good morning.

(4) EXPLICIT ATTRIBUTION, that is, indicating to hearing-impaired viewers that a foreign language is spoken, as in:

\section{[IN FRENCH]}

(5) LINGUISTIC HOMOGENISATION, that is, avoiding the indication of the presence of a foreign language in dialogue at all, as in:

Good morning.

Strategies for subtitling foreign languages present in a film for a hearingimpaired audience depend on the nature of the film, on the role of multilingualism in the film, and on whether foreign dialogue in the film is pre-subtitled for the primary target audience. In the case of films which contain extensive foreign dialogue translated for the primary (hearing) target audience in the form of pre-subtitles, the main strategies which can be used in subtitling for the hearing-impaired in a secondary market are colour-coding, linguistic homogenisation and explicit attribution combined with translation. When subtitling a film where foreign dialogue was not translated for the primary audience in the form of pre-subtitles, the SDH subtitler may choose between vehicular matching or explicit attribution to denote the presence of foreign dialogue for the hearing- 
impaired audience. At present it is explicit attribution that is usually employed in the overwhelming majority of subtitles for the deaf and hard of hearing.

It is worth noting that the strategy of explicit attribution can be used either on its own or in combination with translation. Foreign dialogue pre-subtitled for the primary target audience will probably also be translated for the secondary audience. In this case, the translated utterance can be preceded by the information that foreign language is spoken (see strategy 2 above). When foreign dialogue has not been presubtitled for the primary audience, subtitles for hearing-impaired viewers usually contain information about which language is spoken, but no translation of the utterance is provided (see strategy 4).

Below we report on a study of different SDH carried out among Polish people with hearing impairments with a view to finding out which strategies they like best, depending on whether the foreign language in a film was pre-subtitled for the primary audience or not. In Szarkowska et al. (2013) we presented the overall preferences of hearing-impaired viewers with regard to the five SDH strategies outlined above. In this article, we look at only those participants who indicated that they did not know the foreign language used in the excerpts.

\subsection{Study participants}

A total of 135 deaf and hard of hearing people took part in the study. The participants were recruited through d/Deaf portals, d/Deaf associations, the website of the research group AVT Lab ${ }^{3}$ and social networking. Each participant was asked to state their degree of hearing loss, defined in decibels. Out of the total number of 135 participants, 33 had a moderate hearing loss (41-70 dB), 33 severe hearing loss (71-90 dB) and 69 were profoundly deaf (more than $90 \mathrm{~dB}$ ). No people with mild hearing loss (21-40 dB) took part in the study. Most participants were either born deaf $(N=81,60 \%)$ or lost hearing by the age of three $(N=36,27 \%)$, which means their hearing loss was pre-lingual. This in turn has the implication that the mother tongue of most participants is not Polish but Polish Sign Language, their primary language of everyday communication. Polish is therefore the first foreign language of this group of participants.

Apart from the degree of hearing loss, the participants were also asked to declare their command of four foreign languages used in the study (English, French, Italian and German) on a 5-point scale where "1" meant "I don't know the language at all" and "5" stood for "I am fluent in it" (see Table 1). 
Table 1: Command of foreign languages among study participants

\begin{tabular}{|l|l|l|l|l|l|l|l|l|l|l|}
\hline & \multicolumn{2}{|l|}{1} & \multicolumn{2}{l}{2} & \multicolumn{2}{l|}{3} & 4 & \multicolumn{2}{l|}{5} \\
\hline & $\begin{array}{l}\text { Coun } \\
\mathrm{t}\end{array}$ & $\%$ & $\begin{array}{l}\text { Coun } \\
\mathrm{t}\end{array}$ & $\%$ & $\begin{array}{l}\text { Coun } \\
\mathrm{t}\end{array}$ & $\%$ & $\begin{array}{l}\text { Coun } \\
\mathrm{t}\end{array}$ & $\begin{array}{l}\text { Coun } \\
\mathrm{t}\end{array}$ & $\%$ \\
\hline $\begin{array}{l}\text { Englis } \\
\mathrm{h}\end{array}$ & 32 & $\begin{array}{l}23 . \\
7\end{array}$ & 35 & $\begin{array}{l}25 . \\
9\end{array}$ & 37 & $\begin{array}{l}27 \\
4\end{array}$ & 16 & $\begin{array}{l}11 . \\
9\end{array}$ & 15 & $\begin{array}{l}11 . \\
1\end{array}$ \\
\hline French & 122 & $\begin{array}{l}90 . \\
4\end{array}$ & 4 & 3.0 & 2 & 1.5 & 1 & 0.7 & 6 & 4.4 \\
\hline Italian & 125 & $\begin{array}{l}92 . \\
6\end{array}$ & 3 & 2.2 & 1 & 0.7 & 1 & 0.7 & 5 & 3.7 \\
\hline $\begin{array}{l}\text { Germa } \\
\mathrm{n}\end{array}$ & 92 & $\begin{array}{l}68 . \\
1\end{array}$ & 26 & $\begin{array}{l}19 . \\
3\end{array}$ & 8 & 5.9 & 4 & 3.0 & 5 & 3.7 \\
\hline
\end{tabular}

Most participants were not proficient in any of the foreign languages used in the study. The foreign language best known to them was English, followed by German. Given the fact that the largest number of participants had a pre-lingual hearing loss and used Polish as their first foreign language, other oral languages such as English, French, German or Italian took up the place of second, third, etc., foreign language, therefore being even more of a challenge to these participants. In the results presented here we took into consideration only those responses from participants who indicated not having any command of a foreign language used in the film excerpts. For instance, in clip 4, which is an excerpt from Life is beautiful (Benigni, 1997), we analysed only the results for 92 participants who answered " 1 " when replying to the question whether they understood German.

\subsection{Study procedure}

The study was administered online through a dedicated space on the website of the research group AVT Lab, using the SurveyGizmo system. Anyone who had the link could access the website but, thanks to appropriate settings of cookies, the same person could only complete the survey once. Conducting the online study allowed us to reach people who live in Poland and abroad.

Participants were first asked personal information such as their age, degree and onset of hearing loss, and command of foreign languages. They were then presented with pairs of clips from Inglourious Basterds, 2 Days in Paris and Life is Beautiful. Each clip was shown with two different versions of subtitles for the deaf and hard of hearing and the respondents were asked which version they preferred and why (optional 
open question). They could also choose the "I don't mind" option in each case. Before watching the clips, viewers were provided with a written synopsis of the film, in Polish, and a short presentation of the scene's context. We also informed participants whether the foreign language in the excerpt was translated for hearing viewers or not.

\subsection{Results and discussion}

- $\quad$ Clip 1 Inglourious Basterds: Explicit attribution of language versus linguistic homogenisation

Inglourious Basterds (Tarantino, 2009) is set in France during World War II and is "a cod-second world war adventure about a Jewish-American revenge squad sent into occupied France to spread terror among Nazis" (Bradshaw, 2009, online). The squad is recruited and led by Captain Aldo Raine, "a Gentile from the Deep South" (French, 2009, online). Aldo Raine is, as put by Wood, "a Tennessee hillbilly" (2009, p. 18), who speaks with "a slow, southern drawl" (Fryer \& Romero Fresco, forthcoming).

Throughout the movie, the characters - many of whom turn out to be polyglots - speak four different languages: English, German, French and Italian, which play an important role in the narrative. The presence of such a large number of languages and the high frequency of codeswitching serve as markers of authenticity, so often disregarded in World War II films. According to O'Sullivan (2011), some scenes from Inglourious Basterds can be regarded as "a sly wink to the many Second World War films in which language is treated more cavalierly" (p. 3).

Tarantino provided his primary English-speaking audience with a pre-subtitled version of all the French, Italian and German utterances. In relation to this, Wood (2009) wonders in his review of Inglourious Basterds:

the film is spoken in German and French for most of its duration, with large excursions into English and a brief comic scene in Italian. The language in each case is very elaborate, almost baroque, and an essential part of the fun. What are we to do if we have only the subtitles to go by? How shall we grasp, let alone enjoy the moment when a German actor playing an English soldier is caught out by another German because of the imperfections of his German accent? (p. 18)

These rhetorical questions aptly reflect the typical attitude of Englishspeaking audiences when confronted with foreign language dialogue. When the film was released on DVD in Poland, all the four languages were post-subtitled for Polish hearing viewers. The Polish DVD edition 
of the film did not include a separate subtitle track for the hearingimpaired, which means they had to rely solely on the version for the hearing and were not informed about the presence of multiple languages spoken in the film and the frequent code-switching.

The film consists of five chapters, the first of which is set in rural France. A French farmer, LaPadite, is visited by German troops whose "leader is SS Colonel Landa [...], a suave, charismatic sadist charged with hunting for fugitive Jews" (French, 2009, online). Landa starts interrogating LaPadite in flawless French in "a wheedling, menacingly playful, manipulative manner" (French, 2009, online) - he knows that LaPadite is hiding a Jewish family under the floor of his house and that the family do not speak English. After a short exchange in fluent French with LaPadite, Landa asks for his permission to switch to English. "Is Tarantino compromising by this language switch?", asks a reviewer (French, 2009, online), pointing to a typical solution by which a diegetic code-switching is used not only for the story but for the purpose of being understood by the English-speaking primary target audience. And the same reviewer continues: "No, it's part of Landa's deadly strategy of getting LaPadite to betray himself." In English, as requested by Landa, the farmer confesses he is hiding the fugitives, after which the colonel calls in his men to execute the Jewish family. The soldiers fire into the wooden floorboards and kill everyone except for one girl, Shoshanna, who escapes to Paris and seeks her revenge a few years later.

The question we posed in relation to this clip was whether the code-switch from English into French in this scene should be indicated in SDH. We hypothesised that, since it is explicitly discussed in the dialogue (subtitled into Polish for hearing viewers) by the characters themselves, viewers with hearing impairments may find it unnecessary. We therefore provided the study participants with two versions of the clip, one using the linguistic homogenisation strategy, where the code switch was not signalled in any way, and the other with the explicit attribution strategy, where the code switch was marked in square brackets: 
Figure 1: Linguistic homogenisation versus explicit attribution in Inglourious Basterds

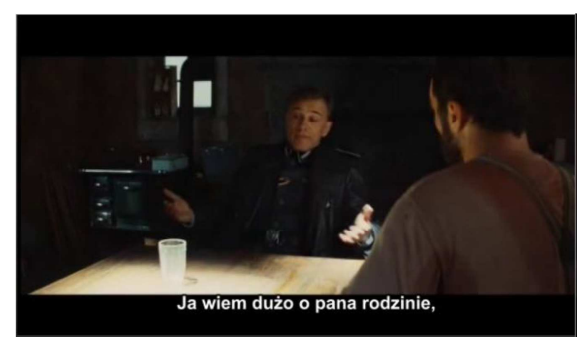

I'm very familiar with you and your family,

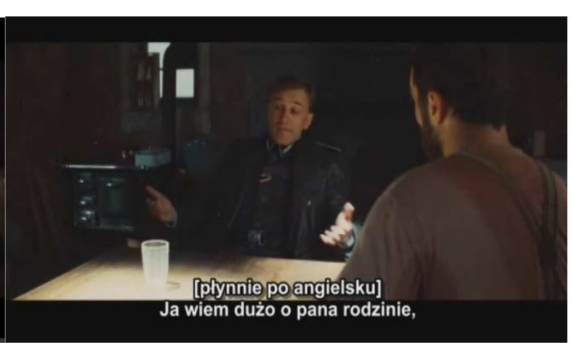

[fluently in English]

I'm very familiar with you and your family,

When offered the choice between linguistic homogenisation, which did not mark in SDH the code-switch between French and English, and explicit attribution, most participants stated they preferred the latter strategy (see Table 2 below). Almost one-third of respondents said, however, that they did not mind which strategy was used. This may be due to the fact that the code-switch may be inferred from the scene and dialogue. While almost half of the participants opted for the explicit attribution strategy and about one-third had no preference, only about one in five people said they preferred the linguistic homogenisation strategy.

Table 2: Preferences for linguistic homogenisation versus explicit attribution in Clip 1 (percentages)

\begin{tabular}{|l|l|l|l|l|}
\hline Hearing loss & $\begin{array}{l}\text { Linguistic } \\
\text { homogenisation }\end{array}$ & $\begin{array}{l}\text { Explicit } \\
\text { attribution }\end{array}$ & $\begin{array}{l}\text { I don't } \\
\text { mind }\end{array}$ & Total \\
\hline Moderate & 27.3 & 21.2 & 51.5 & 100 \\
\hline Severe & 9.1 & 60.6 & 30.3 & 100 \\
\hline Profound & 24.6 & 52.2 & 23.3 & 100 \\
\hline Average & 21.5 & 46.7 & 31.9 & 100 \\
\hline
\end{tabular}

Interestingly, it was participants with moderate hearing loss who stated most frequently that they did not mind which strategy was used, whereas people with severe or profound hearing loss chose the "I don't mind" option in the questionnaire less frequently. Similarly, the explicit 
attribution strategy was preferred by those with severe and profound hearing loss. It seems plausible to assume that viewers with moderate hearing loss were still able to hear the code-switch and did not need it to be marked explicitly in the subtitles, whereas other viewers were unable to rely on residual hearing and thus expected the code-switch to be indicated.

- Clip 2 Inglourious Basterds: Explicit attribution of accent versus explicit attribution of language

In the fifth chapter of Inglourious Basterds, there is a scene where "multilingualism breaks down" (O'Sullivan, 2011, p. 3). In this scene, Aldo Raine and two other members of his squad attend a film premiere disguised as Italians, although they do not speak any Italian. Accompanied by a German actress, Bridget von Hammersmark, they encounter colonel Landa, who - after exchanging a few words with Bridget in their native German - surprisingly addresses the alleged Italian filmmakers in fluent Italian. The response he receives is a simple Buongiorno, uttered by Aldo Raine with "a hilariously chewy Tennessee accent" (Emerson, 2009, online), which betrays the true origin of the Basterds and gives the scene a comic character.

In our study, we decided to test whether the participants would find it important for the foreign accent, and not just the foreign language, to be marked in SDH. Explicit attribution of language was used in one version of the clip, while the other contained information about both the language and the heavy southern American accent:

Figure 2: Explicit attribution of language versus explicit attribution of accent in Inglourious Basterds

\section{Clip 2.1: EXPLICIT ATTRIBUTION OF LANGUAGE \\ Clip 2.2: EXPLICIT ATTRIBUTION OF LANGUAGE}

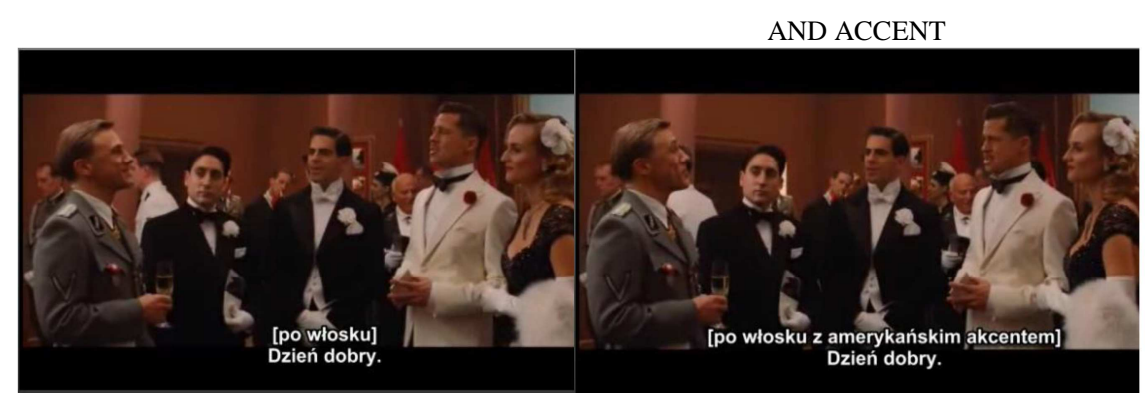

[in Italian] Buongiorno.

[in Italian with American accent] Buongiorno 
The vast majority of participants indicated that their preferred strategy was explicit attribution of language and accent (see Table 3). The group who particularly favoured this strategy were people with profound hearing loss. About one-third of participants with moderate and severe hearing loss stated they did not mind which strategy was used. The strategy of explicit attribution of language only was the least favoured among viewers with moderate and severe hearing loss. All in all, most participants - none of whom knew any Italian - opted for the information about the accent to be included in subtitles alongside information about the language.

Table 3: Preferences for explicit attribution of language versus explicit attribution of accent in Clip 2 (percentages)

\begin{tabular}{|l|l|l|l|l|}
\hline Hearing loss & $\begin{array}{l}\text { Explicit } \\
\text { attribution of } \\
\text { language }\end{array}$ & $\begin{array}{l}\text { Explicit attribution } \\
\text { of language and } \\
\text { accent }\end{array}$ & $\begin{array}{l}\text { I don't } \\
\text { mind }\end{array}$ & Total \\
\hline Moderate & 17.2 & 51.7 & 31.0 & 100 \\
\hline Severe & 22.6 & 48.4 & 29.0 & 100 \\
\hline Profound & 27.7 & 60.0 & 12.3 & 100 \\
\hline Average & 24.0 & 55.2 & 20.8 & 100 \\
\hline
\end{tabular}

- $\quad$ Clip 32 days in Paris: Colour-coding versus explicit attribution

2 Days in Paris (Delpy, 2007) is a "comedy about Marion, a Parisienne photographer living in New York who, en route from a holiday in Venice, gives her American boyfriend, interior designer Jack, a whirlwind tour of Paris, her family and her friends" (Calhoun, 2007, online). The fact that Jack does not speak French and that a number of French people he meets, including Marion's parents, do not speak much English is a source of numerous misunderstandings and comical situations, making Jack experience "a fraught and life-changing couple of days" (Bradshaw, 2007, online).

A New York Times review of 2 Days in Paris informed its readers that the film was "written (in English and French, with English subtitles), directed and edited by Julie Delpy" (Holden, 2007, online). Indeed, the dialogue list is a mix of French and English, which practically makes the film bilingual. This, in turn, made it necessary to provide the Englishspeaking audience with the subtitled translation of all the French dialogue. 
Polish hearing viewers were provided with a subtitled translation of both English and French dialogue. When preparing subtitles for the hearing-impaired, it seems crucial that the viewers be informed about the bilingual nature of the dialogue, constant code-switching and any resultant miscomprehension/confusion when characters are trying to communicate. Traditionally, the presence of a foreign language is marked in SDH using the explicit attribution strategy, which was the first option in our study. Another option was the strategy of colour-coding, where all the French dialogue was translated into Polish and marked in blue, as opposed to the traditional whiteness of utterances translated from English:

Figure 3: Explicit attribution of language versus colour-coding in 2 Days in Paris

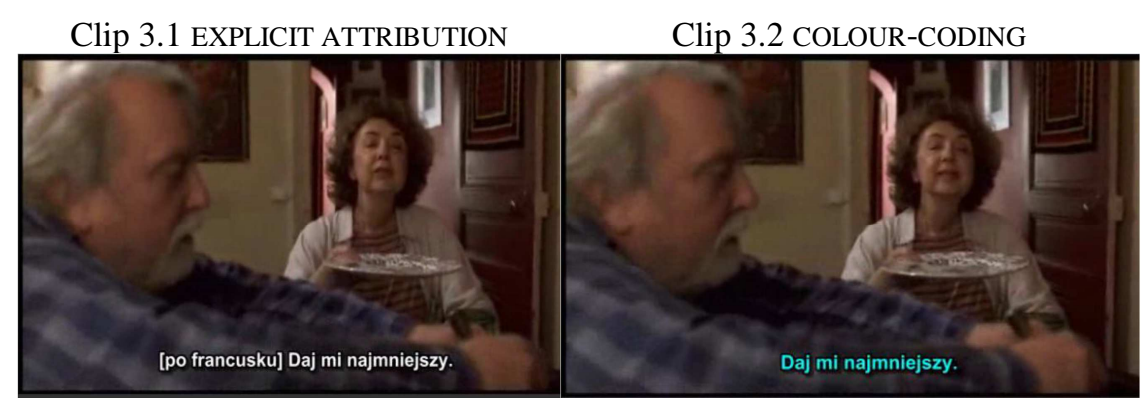

[in French] Give me the smallest one.

Give me the smallest one.

After watching the clip with the two versions of subtitles, more than 50\% participants (none of whom had any knowledge of French) stated they preferred the colour-coding strategy (see Table 4 below). This is particularly interesting as colours are normally used in SDH for speaker identification (main characters are allocated colours, as opposed to other characters who speak "in white"). The choice of the colour-coding strategy may in this particular case be attributed to the fast pace of the dialogue.

In contrast to colour-coding, the explicit attribution strategy inevitably raises the required subtitle reading speed and makes it more difficult to follow the dialogue as it contains significantly more text: almost each time a character speaks, the translation of the utterance is preceded by information in brackets denoting which language is spoken. An interesting solution was proposed by one of the study participants, who suggested using an abbreviated version of the text in brackets, e.g. [fr.] or [franc.], instead of the full version [po francusku] ("in French"). 
Yet another potentially useful suggestion came from a participant who stated that, instead of a different colour, a different typeface could be employed for changes of language.

Table 4: Preferences for explicit attribution versus colour-coding in Clip 3 (percentages)

\begin{tabular}{|l|l|l|l|l|}
\hline Hearing loss & $\begin{array}{l}\text { Explicit } \\
\text { attribution }\end{array}$ & Colour-coding & I don't mind & Total \\
\hline Moderate & 24.1 & 48.3 & 27.6 & 100 \\
\hline Severe & 35.5 & 45.2 & 19.4 & 100 \\
\hline Profound & 22.6 & 59.7 & 17.7 & 100 \\
\hline Average & 26.2 & 53.3 & 20.5 & 100 \\
\hline
\end{tabular}

Again, the option "I don't mind" was most frequently selected by participants with moderate hearing loss, whereas people with severe or profound hearing loss clearly preferred the colour-coding strategy.

- Clip 4 Life is beautiful: Vehicular matching versus explicit attribution

Life Is Beautiful (Benigni, 1997) tells a story of a Jewish Italian, Guido, played by Roberto Benigni, and his son Giosué, who are taken into a concentration camp during World War II. In an attempt to protect his son, Guido pretends it is all just a game. Having just arrived at the camp, Guido volunteers as a German-Italian interpreter, despite not speaking a word of German. His pseudo-interpreting of the instructions barked by a Nazi soldier, in which he perfectly imitates the intonation and body language of the soldier while at the same time managing to keep up appearances, creates a hilarious scene whose comic quality also relies on the contrast between the gravity of the situation and playfulness of Guido's mistranslation: "there is comedy in the incongruous juxtaposition of the guard's angry shouts and Guido's exhortations" (O'Sullivan, 2011, p. 88). One may argue that the scene gains an even more comic character when the audience, just like Guido, does not understand the German utterances. 
Figure 4: Vehicular matching versus explicit attribution in Life is beautiful

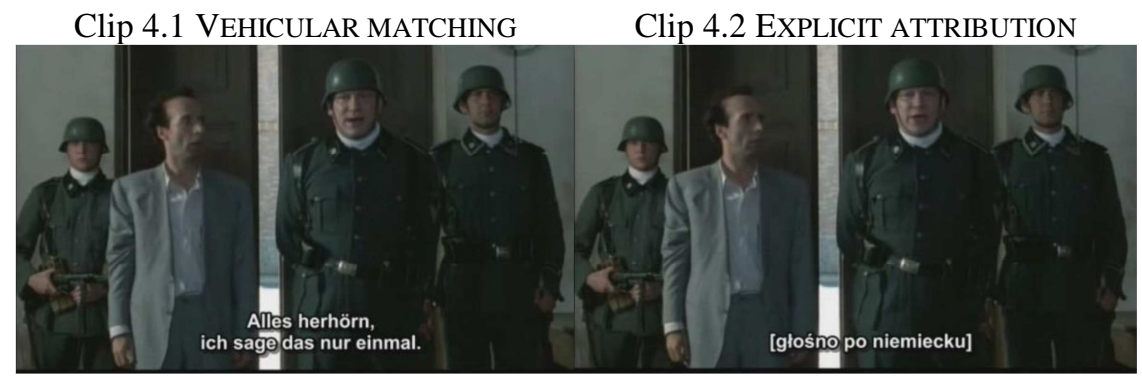

Alles herhörn,
ch sage das nur einmal.

The instructions given by the soldier are not pre-subtitled for the hearing, primary target audience in Italy, nor for the secondary audience in Poland. Therefore, the question of what should be done in subtitling for the Polish hearing-impaired is particularly interesting in this case. As argued by Bartoll (2006), "it would seem reasonable that one should translate what has already been translated in the original version" (p. 1); thus, the option of translating the German utterances does not seem feasible, since the creators of the film decided not to provide their original audience with such a translation.

In our study, we offered the participants two types of subtitles: one using the explicit attribution strategy traditionally employed in SDH in such cases, which consists of stating in brackets which language is spoken; the alternative set of subtitles used vehicular matching where the actual German words shouted by the soldier were transcribed and shown in the subtitles (see Figure 4).

Indeed, as Shohat and Stam point out:

in the case of the subtitled film, we hear the more-or-less alien sounds of another tongue. If the language neighbours are our own, we may recognise a substantial proportion of the words and phrases. If more distant, we may find ourselves adrift on an alien sea of undecipherable phonic substance. (1985 in Betz, 2009, p. 87)

Just as hearing viewers encounter the "undecipherable phonic substance" when watching a foreign film, so hearing-impaired viewers with no knowledge of the foreign language can be confronted with the experience of the foreign "undecipherable visual substance" through vehicular 
matching. Since subtitles for the deaf and hard of hearing are supposed to transform the content of messages from the verbal auditory channel into the verbal visual channel (see Gottlieb, 1998), our hypothesis was that, in a similar way to hearing viewers who are immersed in the experience of the foreign by hearing the German instructions, the hearing-impaired viewers can likewise be immersed in the situation by seeing what the German soldier actually says.

Table 5: Preferences for explicit attribution versus explicit attribution in Clip 4 (percentages)

\begin{tabular}{|l|l|l|l|l|}
\hline Hearing loss & $\begin{array}{l}\text { Vehicular } \\
\text { matching }\end{array}$ & $\begin{array}{l}\text { Explicit } \\
\text { attribution }\end{array}$ & $\begin{array}{l}\text { I don't } \\
\text { mind }\end{array}$ & Total \\
\hline Moderate & 37.5 & 29.2 & 33.3 & 100 \\
\hline Severe & 45.5 & 22.7 & 31.8 & 100 \\
\hline Profound & 43.5 & 39.1 & 17.4 & 100 \\
\hline Average & 42.4 & 32.6 & 25 & 100 \\
\hline
\end{tabular}

Having watched the two subtitled versions of the excerpt, more than $40 \%$ of the participants - none of whom had any knowledge of German stated they preferred vehicular matching, whereas one-third said they favoured explicit attribution. Vehicular matching was the strategy most frequently chosen by all groups of participants, regardless of their hearing loss. Only 25\% participants did not mind which SDH strategy should be used in this context.

According to O'Sullivan (2011), "vehicular matching can be seen as a resistant strategy" (p. 114). In SDH, this strategy is undoubtedly more demanding on the part of the subtitler than explicit attribution, which requires the subtitler only to recognise the foreign language and to name it in subtitles. It may also be more difficult in terms of technicalities, particularly in the case of more exotic languages which sometimes use a different alphabet.

\section{Conclusions}

The growing presence of multiple languages on screen and, thus, the increasing visibility of multilingualism reflects "the exotic lure of the foreign, indicated through geographic, cultural and/or linguistic markers", which "in many ways represents the backbone of the cinema industry" (Dwyer, 2005, p. 295). According to O'Sullivan (2011), "the growing visibility of translation within the mainstream cinema has the potential to [...] promote the development of 'multilingual imagination' in multiplex 
cinemagoers" (p. 81). One of the ways to promote "multilingual imagination" among viewers with hearing impairments, who often miss out on the multilingual nature of films, lies, as shown by the findings of our study, in using SDH strategies which are more informative of multilingual content. Vehicular matching is an example of such strategy. Not only should the presence of a foreign language be indicated in SDH, but also foreign accent needs to be marked whenever necessary.

As we hope to have shown in this article, the importance of presubtitling and the type of audience cannot be underestimated when deciding which SDH strategy should be chosen. If the film creators did not provide their primary hearing viewers with pre-subtitles, the results of our research suggest that SDH subtitlers should consider using the vehicular matching strategy. This strategy allows the audience to become immersed in the foreign through actually seeing what other viewers can hear. If the primary audience were provided with pre-subtitles, another option besides explicit attribution, frequently used in this case, would be colour-coding, which met with a favourable reception from the participants of our study.

In this article we looked at only a limited number of film excerpts, languages and strategies, and we analysed responses exclusively from participants with no knowledge of the foreign languages in question. Other languages, films and subtitling solutions are available that may open up new research avenues. One interesting aspect worth examining is that of which SDH strategies can be used when a multilingual film is imported to a country where the language which was foreign to the primary target audience is known by the secondary audience (see Díaz Cintas, 2011). For instance, what would be the preferred SDH strategy to render the German in Life is beautiful for German hearing-impaired viewers?

\section{References}

Bartoll, E. (2006). Subtitling multilingual Fflms. In M. Carroll, H. GerzymischArbogast, \& S. Nauert (Eds.), MuTra 2006 - Audiovisual translation scenarios: Conference Proceedings. Available at: http://www.euroconferences.info/proceedings/2006_Proceedings/2006_Bartol 1_Eduard.pdf [Accessed 20 April 2013]

Betz, M. (2009). Beyond the subtitle: Remapping European art cinema. Minneapolis, MN: University of Minnesota Press.

Bradshaw, P. (2007). Two Days in Paris. The Guardian. www.guardian.co.uk/film/2007/aug/31/worldcinema.romance. [Accessed 20 April 2013]

Bradshaw, P. (2009). Inglourious Basterds. The Guardian. http://www.guardian.co.uk/film/2009/aug/19/inglourious-basterds-reviewbrad-pitt-quentin-tarantino. [Accessed 20 April 2013] 
Calhoun, D. (2007). 2 Days in Paris. TimeOut. http://www.timeout.com/london/film/2-days-in-paris. [Accessed 20 April 2013]

Díaz Cintas, J. (2003). Audiovisual translation in the third millennium. In G. Anderman \& M. Rogers (Eds.), Translation today: Trends and perspectives (pp. 192-204). Clevedon: Multilingual Matters.

Díaz Cintas, J. (2011). Dealing with multilingual films in audiovisual translation. In W. Pöcki, I. Ohnheiser, \& P. Sandrini (Eds.), Translation Sprachvariation Mehrsprachigkeit,(pp. 215-233). Frankfurt: Peter Lang.

Dwyer, T. (2005). Universally speaking: Lost in Translation and polyglot cinema. Linguistica Antverpiensia New Series, 4, 295-310.

Emerson, J. (2009). Some ways to watch Inglourious Basterds. Scanners: Blog, 24 August 2009, available on http://blogs.suntimes.com/scanners/2009/08/ some_ways_to_watch_inglourious.html. [Accessed 20 April 2013].

French, P. (2009). Inglourious Basterds. The Observer. http://www.guardian.co.uk/film/2009/aug/23/inglourious-basterds-philipfrench.[Accessed 20 April 2013]

Fryer, L., \& Romero-Fresco, P. (forthcoming). Audiointroductions. ADLab project.

Gottlieb, H. (1998). Subtitling. In M. Baker (Ed.), Routledge encyclopedia of translation studies (pp. 244-248). London: Routledge,.

Holden, S. (2007). Comprenez-Vous Woody Allen Films? Here's a Paris Version. New York Times. http://movies.nytimes.com/2007/08/10/movies/10pari.html. [Accessed 20 April 2013]

O'Sullivan, C. (2008). Multilingualism at the multiplex: A new audience for screen translation? Linguistica Antverpiensia New Series, 6, 81-95.

O'Sullivan, C. (2011). Translating popular film. Basingstoke: Palgrave Macmillan.

Shohat, E., \& Stam, R. (1985). The cinema after Babel: Language, difference, power. screen, 26(3-4), 41. doi:10.1093/screen/26.3-4.35

Sternberg, M. (1981). Polylingualism as reality and translation as mimesis. Poetics Today, 2(4), 221-239.

Szarkowska, A., Żbikowska, J., \& Krejtz, I. (2013). Subtitling for the deaf and hard of hearing in multilingual films. International Journal of Multilingualism, 10(3), 292-312. doi: 10.1080/14790718.2013.766195

Wahl, C. (2005). Discovering a genre: The polyglot film. Cinemascope - Independent Film Journal, 1, 1-8.

Wood, M. (2009). At the movies. Inglourious Basterds. London Review of Books. http://www.lrb.co.uk/v31/n17/michael-wood/at-the-movies. Vol. 31 No. 17, 10 September 2009, page 18. [Accessed 20 April 2013]

\section{Filmography}

Bender, L. (Producer), \& Tarantino, Q. (Director). (2009). Inglourious Basterds [Motion picture]. United States: Universal Pictures. 
Braschi, G. (Producer), \& Benigni, R. (Director). (1997). Life Is Beautiful [Motion picture]. Italy: Cecchi Gori Group Tiger Cinematografica \& Melampo Cinematografica.

Delpy, J. (Producer), \& J. Delpy (Director). (2007). 2 Days In Paris [Motion picture]. France: Polaris Film Production \& Finance.

1 Sternberg's model of linguistic representation was created with literature in mind but we believe, like O'Sullivan (2011), that it can also be applied to film.

2 We say "usually" because some films have only a voiced-over - not a subtitled - version.

3 AVT Lab's website can be found at www.avt.ils.uw.edu.pl. 